\title{
Consumer preferences using the method BW Score: A study of Brazilian consumer's perception
}

\author{
C. Neumann da Cunha, H. Dewes, and M.V. Araújo \\ CEPAN, Agribusiness Program, 91540-000 Av. Bento Gonçalves 7712 Porto Alegre, RS, Brazil
}

\begin{abstract}
Purpose Identify the most important attributes used by consumers in Porto Alegre (Brazil) in the wine selection process. Originality/value: The behavior of the wine consumer is changing, since people have different wants and needs which are influenced by several factors. Among these factors, the attributes of the product are relevant to understanding the decision-making process of the consumer. Understanding such behavior is fundamental for the development of the market, since it is the consumer who determines what and how many products will be acquired. In this sense the research becomes relevant for a better understanding of the behavior of the wine consumer in the Brazilian market. Design/methodology/approach: A qualitative exploratory study through interviews with two experts in Porto Alegre (Brazil) to investigate the relevance of the attributes proposed in the literature review. The results reaffirmed the need to use 13 attributes. Later an online questionnaire was applied to 100 wine consumers. Therefore, in this work, a BIB $(13,4,4,1)$ was generated for further analysis using the BW score. As a complement, ANOVA was used to analyze the mean differences between attributes and segments. Findings: The results obtained showed that the most important attributes are related to the previous experience of the consumer with wine, gastronomic harmonization and recommendations.
\end{abstract}

Keywords: Consumer behavior; Wine; Product attributes.

\section{Introduction}

The analysis of the world panorama of wine consuming countries indicates that the United States of America was the country that most consumed wine in 2017. However, Italy ranked first in the ranking of the largest wine producers, surpassing other traditional countries in the manufacture of drink, such as United States and France. In the same year, Brazil occupied the eighteen places as a consumer (OIV, 2017).

But why are Brazilians consuming more wine? One of the reasons is the phenomenon of globalization that facilitated the entry and exit of products in the country, expanded world trade and consequently increased competition, thus improving the quality of manufactured products (Fernandes Neto, 2006). It is noticed that changes are happening in the behavior of the consumers of this drink. Understanding this behavior is fundamental for the development of this market, after all it is the consumer who determines what and how many products will be acquired. However, identifying the profile of the consumer and understanding their behavior is not a simple task, since people have different desires and needs, which are influenced by several factors (Kotler, 1998).

Among these factors, the attributes of the product constitute a relevant element to understand consumer decision-making (Urdan; Nagão, 2004, p.3). Therefore, marketing researchers tend to explain consumers' preferences by measuring and analyzing the importance of product attributes at the time of purchase. When the consumer buys a product, he analyzes characteristics such as brand, price, packaging, among others, to make his final decision. However, the level of influence attributes have on the consumer varies according to the product and the profile of the people (Engel et al., 2000).

There are also other studies that investigated the relevance of wine attributes at the time of purchase (Groot, 2011), but there are few empirical studies that investigate the behavior of wine consumers in Brazil. In view of this problem, the general objective of this study is to analyze the relevance of the attributes of the wine in the decision making process of this product for the consumers of Porto Alegre, promoting a better understanding on the behavior of the wine consumer in the national market.

\section{Changes in the wine market}

In the 1990s, the stabilization of the Brazilian economy and the opening up to imports boosted the consumption of fine wines among the middle class (Malheiro, 2006). The increase in the purchasing power of the middle class, coupled with a greater supply of world products, enabled this segment of the population to access products previously consumed exclusively by high-income consumers. However, the globalization process did not favor the consumption of national fine wines. According to Mello (2002) this reality is justified due to the Brazilian's lack of habit to drink wine and preference for imported products. In the opinion of the author, in order for national producers to regain and increase their participation in 


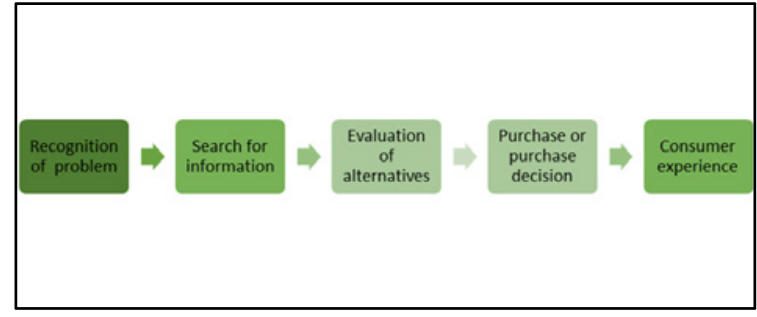

Source: (SHETH, 2001, p. 486)

Figure 1. Customer decision-making process.

the Brazilian fine wine market, efforts must be directed towards encouraging consumption and changing consumer habits through advertising campaigns, fairs and events (Mello, 2002).

On the other hand, the process of wine standardization - a strategy combated by the producers and consumers of the so-called Old World - has contributed to the democratization of the consumption of this drink (Roese, 2008). The industrial production technology employed by most New World wineries has been responsible for standardizing the product and its massification in the market. In this way, the wine market becomes more diversified, since at the same time it encompasses the terroir concept of the Old World wines and the standardization of wines from the New World newly wine producing countries - as well as organic wines (Sloan, 2005) offering the consumer a greater variety of products.

In addition to the variety of products available in the market, the norms of etiquette for the consumption of fine wines - such as knowledge about the appropriate temperature, the use of specific glasses and notions that guarantee the correct harmonization of the drink with the food (Roese, 2008) - require the consumer's highest qualification for their "correct" purchase and tasting. Therefore, the level of demand and knowledge of these consumers tends to be higher (Mello, 2002).

In addition, wine has become a fashionable subject. There are a number of services and products available to the middle class aiming to provide information on the "wine art". Courses, tasting classes, sommelier training courses, television programs and specialized magazines are available to this new consumer so that he can also become knowledgeable about the subject.

Faced with these changes in the scenario of wine production and consumption, consumer behavior has also undergone changes. To understand and identify variations in people's behavior in acquiring wines and future buying trends for that beverage, companies need to do a study of consumer behavior, which will be covered in the next section.

\section{The consumer decision process and product atributes}

The consumer decision process is divided into stages. For some researchers, this process occurs in five stages: 1 - recognition of the need or problem; 2 - Search for information or pre-purchase search; 3 - Evaluation of alternatives; 4 - Purchase decision; 5 - Post-purchase evaluation or post-consumer experience (Fig. 1). Other authors add two more steps to the process (Blackwell et al., 2009), which are consumption and disposal.

Among these stages, two of them seem to be more important so that we can identify and analyze the attributes that are most relevant in the decision-making process of buying a wine: the evaluation of alternatives and the decision of purchase. The first step in the purchasing decision process is recognition of the problem. The individual recognizes the problem when there is a need to be satisfied, as it compares its current state with the ideal state and realizes that there is a condition of lack, discomfort or deprivation, be it physical or psychological (Stefano et al., 2008).

After recognizing the problem, the consumer searches for information about the product - such as its attributes, functions, durability and other aspects, in advertisements, opinions of friends, sellers, etc. - to base their decisionmaking on the products available (Kotler, 1998) and to analyze the alternatives that indicate the best business (Las Casas, 2010). Since each product has different characteristics, it is consumers who determine which ones will be most important in their evaluation (Kotler, 1998). The consumer pre-selects a small number of brands that he considers acceptable and uses criteria to evaluate each brand and make its buying decision (Shiffman; Kanukhiffman, 2009). Next, the customer chooses the product that is evaluated positively and the purchase is effective (Sheth, 2001: 509). Finally, consumers evaluate their overall satisfaction with the product, analyzing their post-purchase experience, which serves as a feedback mechanism for future purchases (Kotler, 1998).

Product attributes are considered during the evaluation of alternatives - the third stage of the client's decisionmaking process. These elements are the major influencers in consumer buying decision making, so marketers have a tendency to explain consumers' preferences by analyzing product attributes. In addition, by measuring the degree of relevance of attributes to customers, the marketing manager can understand consumer beliefs about a particular product or brand.

Attribute-based choice involves comparing each attribute of the product across multiple brands. Therefore, it requires that consumers be aware of the specific attributes of each product at the time of purchase, generating a decision closer to optimal (Hawkins et al., 2007). Some attributes may influence more than others (Engel et al., 2000) and this influence varies according to the type of product and / or the consumer. The importance that each attribute has for the client refers to the priorities that this client gives to each advantage offered, aiming at their satisfaction (Espinoza; Hirano, 2003). As for the level of influence of the attributes on the purchase decision of a product, the attributes are classified in three ways:

1) Outstanding attributes: they are the attributes that the consumers can perceive, but that do not infer any degree of importance in the purchase decision making.

2) Important attributes: they are evaluated as important at the time of purchase, but do not determine the choice of the product to be purchased. In this way they do not add value to the purchase, since they are present in a similar category of products. 
3) Determining attributes: attributes considered important and capable of influencing the purchase decision, since they are perceived by consumers as the best option to satisfy their desires and needs.

\section{Attributes of wine}

Regarding wine consumption, studies in different contexts investigated the attributes that may influence consumer choice behavior. Goodman et al. (2007) identified thirteen elements that influenced consumer behavior in countries such as Australia, Austria, Brazil, France, Italy, New Zealand and the United States. Of the thirteen items identified, eight were attributes of the product: grape variety; origin of wine; brand; awards; food harmonization; information contained on the back label; attractive front label; alcoholic strength.

There are thousands of varieties of grapes in the world. In accordance Galvão (2004) the grapes can be classified in two categories: non-grapes grapes, also called table grapes, and grapes, suitable for the elaboration of fine wines. The grape varieties present in the traditional regions in the production of wines such as France, Italy, Portugal and Spain were selected naturally over time and adapted to local conditions of soil, climate, and cultural treatment. Over time these species of vines have been taken to other places, like New World countries. In some cases the adaptation of the species was perfect, sometimes exceeding the quality of the original strains, in others, the fruits evolved creating characteristics that escape their originality (Pinto, 2009).

The country of origin is another attribute that influences the evaluation of a product (Gguiloto, 2001; Giraldi, Ilkeda, 2007). People have stereotyped images of each country, and use these images as sources of information to aid in the choice of product they are going to acquire. The country of origin is considered an important factor for wine buyers, because the product has links with its origin. However, the same grape variety grown in different regions produces wines with different flavors (Lattey et al., 2007).

The brand is another very important evaluation criterion, as it reflects the significant value that each product has for its consumers (Rouão; Farhangmer, 2000), besides being the main source of competitive advantage for an organization (Louro, 2000). The image that the consumer has about a particular brand is built through a set of functional, economic and emotional or psychological values (Louro, 2000).

Medals and prizes are also important attributes of influence on consumer preference as they serve as indicators of product quality (Lockshin; Hall, 2003). When a wine is awarded it means that it has been favorably evaluated by experts in relation to other wines. This signals to the buyer that the wine is of high quality and is able to be positively perceived by other people (Mueller, 2009).

The harmonization of wine with food aims to enhance the taste of both. When in harmony, wine and food provide a much greater pleasure than when tasted separately (Queiroz, 2009). However, for a perfect marriage, wine and food need to be compatible. Therefore, it is necessary to know wine well and to know the preparation of the dish with which the wine will be harmonized (Pinto, 2009).
Due to the great variety of wines offered, some consumers are confronted with many decisions. To help them in this choice, the information found on the back label helps them to know more about a certain wine (Lockshin; Hall, 2003). According to Mcgarry \& Thompson (2010), the back labels containing information on wine flavors and aromas influence more than others without these data.

Alcohol is an important component of wine as it is responsible for its preservation and quality as well as providing a burning sensation and warmth when being tasted. The higher the alcohol content of the wine, the greater will be the perception of these sensations. (Miranda, 2001). Another important attribute, but not reported in the research by Goodman et al. (2007), is the price. Among all the products that consumers have acquired over the course of their lives, several of them have been chosen for their value (Engel et al., 2000) and have a strong influence on the decision to buy wines (Magistris et al., 2011 (McGuire; Thompson, 2010).

\section{Behavior of the wine consumer}

For winemakers, the quality of the wine is related to certain parameters traced for the production of this drink, such as method of planting the grape, quantity of fruit sugar, among others. This perception of quality differs from that of the consumer, who considers their preferences and individual tastes when classifying a wine as being of quality. By analyzing consumer preferences, marketing and production teams can target wine types for different consumer categories, or reposition an existing brand of wine to improve sales. One can also check whether the consumer prefers more or less acidity, whether he is more sensitive to choosing a wine by its price, or by the brand, etc. (Lattey et al., 2007).

In France, a country with a tradition of wine production and consumption, the three attributes most cited as relevant in the choice of drink were: harmonization with food, country of origin of the wine and prior knowledge of the product. In Italy, the three preferred items were: previous wine tasting, harmonization with food and country of origin, respectively (Goodman et al., 2007). In Spain, the price factor was evaluated positively, although consumers were more concerned with the harmonization between wine and food and the country of origin (Magistris et al., 2011). In Portugal, wine consumers tended to choose wines with lower prices. However, Hungarian consumers valued more the flavor, quality and country of origin of the wine (Szabo; Szeleszabo, 2006). The attributes most valued by the Austrians were: grape variety, previous wine tasting and country of origin. In Australia, the most important attributes in the decision to buy a wine were: prior knowledge of the wine, recommended by someone and grape variety. A more detailed analysis by types of consumers indicated that the region of origin and the reputation of the winemaker were more important for consumers of high specialization in wine, while for consumers less knowledgeable about the drink, wine style and price had more relevance to choose the product (Johnson; Bastia, 2007).

In the United States, prior knowledge of wine, the recommendation by someone, the grape variety and the country of origin (Lewis, 2010) are the factors that most 


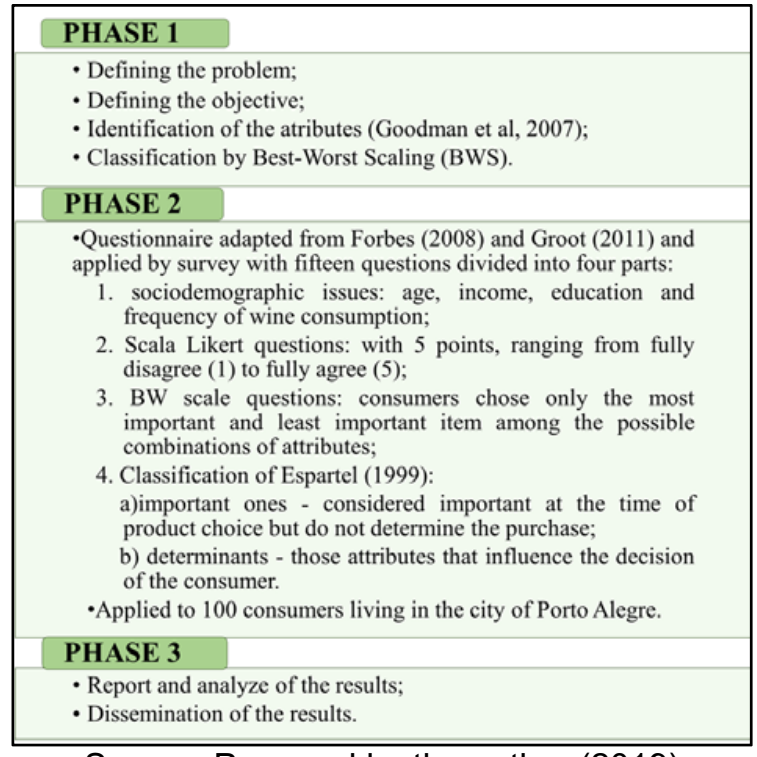

Source: Prepared by the author (2019)

Figure 2. Methodology.

influence the decision to buy the wine. While in Brazil, the brand was cited as an attribute of greater importance in wine selection, followed by prior knowledge of wine and harmonization with food (Goodman et al., 2007).

After reviewing research conducted in other countries, the next section presents the methodology applied to identify the relevance of wine attributes to consumer product purchase, by presenting the research approach, data collection instruments, procedures to define the sample, as well as the technique used to analyze the data, as well as the research limitations.

\section{Methodology}

Theorical framework was constructed based on the identification of the attributes of the wine assiduously evaluated in studies of consumer behavior. Subsequently, the degree of relevance of each attribute was classified by Best-Worst Scaling (BWS). A questionnaire adapted from Forbes (2008) and Groot (2011), applied to 100 consumers living in the city of Porto Alegre, was used as a data collection.

When observing studies carried out in other countries, it is noticed that the quantitative approach has been the most used to research the preferences of the consumers in relation to the attributes of a product. Within this approach, the most used methods were the Ranking, the Pairing Method and the Likert scale. However, more recently, the Best-Worst scale has been suggested, since it allows to study a large set of attributes in a quicker and easier way, avoiding the fatigue of the interviewees that can generate inconsistent and distorted results (Groot, 2011).

Through the Best-Worst Scaling instrument (or BWS, invented by Jordan Louviere in 1987, it is also called Maximum Difference Scaling, or MaxDiff), respondents are invited to indicate between the alternatives offered the best, or the most important, and the worst, or least important attribute of the product (Groot, 2011). In this way, it is possible to identify the maximum difference between the preferences or the degree of importance that the consumer gives to a particular attribute (Erdem et al., 2010). In this method the interviewees can not like or dislike all the attributes. Its intention is to identify the weight of the resulting importance that each attribute has in relation to the others (Lockshin et al., 2009).

BWS questionnaires are relatively easy to understand by most respondents because people are more likely to judge items when they are situated at extremes than to evaluate them by scales that order them in different degrees of importance or preference. The important property of the method is that the scale is free and there is no style of response, a relevant aspect for cross-cultural research. Thanks to these benefits, this method has been used in several studies on consumer behavior. (Sawtoot Software, 2007).

In order to reach the objectives of this work a scale of attributes of the wine was elaborated based on the research of Goodman et al. (2007). The following attributes were considered: grape variety; origin of wine; brand; awards; food harmonization; information contained on the back label; attractive front label and alcohol content. The items - prior knowledge of the wine; recommendation by someone; promotional display in the store; information on the shelf and reading about the wine - were withdrawn because they were not considered attributes of the product. It was also decided to insert in the research the price item because it has been pointed out in other studies as having a high degree of influence on the purchase decision (Magistris et al., 2011; Johnson \& Bastian, 2007; Mcgarry Thompson, 2010), thus totaling nine attributes to be measured.

\section{Data collection instrument}

The data collection instrument used in this study was the multiple choice questionnaire, adapted from the surveys of Forbes (2008) and Groot (2011) and elaborated by the Survey Monkey tool (online research software).

The final result was a questionnaire with 15 questions divided into three parts. The first part was composed of four sociodemographic issues such as age, income, education and gender plus a question about the frequency of wine consumption. The second part consisted of an interval scale, Likert, with 5 points, ranging from fully disagree (1) to fully agree (5). The third and final part consists of questions drawn up on the basis of the BW scale itself, where consumers chose only the most important and least important item among the possible combinations of attributes.

For the construction of the BWS it is necessary to determine the size of the set of choice and the amount of possible combinations to be made between the attributes. According to Groot (2011) the experiment should have at least three alternatives or options of choice in each set and not exceed six alternatives, since the quality of the consumer's response decreases when the number of alternatives increases. Chrzan and Patterson (2006) recommend a larger number of sets with fewer items per question and Orme (2005) proposes that the number of alternatives per set of choice should not be greater than half the total number of attributes, hypothetically, a larger number of items per set results in less precision for items of importance or average preference. 


\begin{tabular}{|rll|}
\hline Atributtes & Countbest & Countworst \\
\hline Grape variety & 194 & 45 \\
Wine of origin Brand & 165 & 23 \\
Harmonization with food & 180 & 64 \\
Information on the back label & 131 & 33 \\
Price & 72 & 81 \\
Brand & 48 & 120 \\
Awards & 45 & 162 \\
Alcohol level & 39 & 179 \\
Front label & 22 & 177 \\
\hline
\end{tabular}

Source: Database analyse (2019).

Taking into account the observations made by Orme (2005), the number of alternatives by combination used in this study was four. As half of the total number of attributes surveyed (9) is equal to a decimal number (4.5) and the number of alternatives in the set must be less than or equal to half the total of attributes, each question of the questionnaire presented a set with four alternatives, which also meets the recommendations of Groot (2011), Chrzan and Patterson (2006).

To define the number of choices sets a function of the total number of evaluated attributes (Ncsets) was used.

In Fig. 3, " $k$ " represents the total number of attributes to be studied (9), " $n$ " is the number of alternatives in each choice set (4) and " $R$ " the number of times each attribute is presented through of the set of choice to each individual, so Ncsets $=9 \mathrm{R} / 4$. But it is still necessary to finish " $R$ ". According to Groot (2011), there were no scientific studies that address this issue and to avoid the fatigue of the interviewees, he decided to repeat each attribute 4 times through sets of choice $(R=4)$, resulting in 9 combinations with 4 attributes each, where all attributes appeared equal and repeatedly 4 times. Based on these guidelines, all the possible combinations were elaborated, that is, to distribute the nine attributes in sets of choice in a balanced way. As each attribute must have equal chance of being chosen, all must appear the same number of times in the questionnaire (Sawtooth Software, 2007).

\section{Sampling}

For this research the Porto Alegre wine consumers represent the universe. Given the impossibility of searching the entire population due to the limitations of time and resources, the solution was to select a smaller group of this universe, but to be as representative as possible. According to Gil (2002) the adequate sample with a confidence coefficient of $95.5 \%$ for a population of more than 100,000 people and with a margin of error of plus or minus $10 \%$ is equal to 100 people.

After the assembly, pre-test and review of the questionnaire, the access links to the Survey Monkey software were sent by email and made available on the social network via online messages or invitation to participate in the event.

\section{Method of data analysis}

To analyze the data collected by the BW scale, we initially calculated the level of importance of each attribute, which is the number of times respondents indicate each attribute

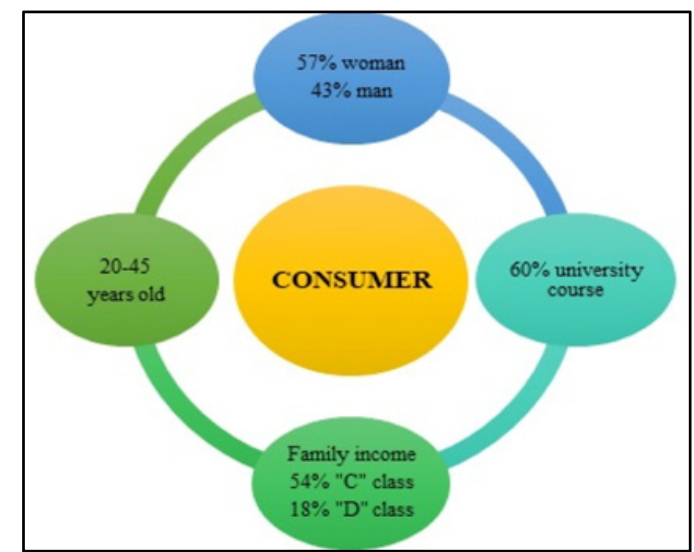

Source: Database analyse (2019)

Figure 5. Sociodemographic issues results.

Table 2. Attributes of wine classified as important by BW Score.

\begin{tabular}{|rll|}
\hline Atributtes & Level of relevance & Score \\
\hline Price & -12 & -0.03 \\
Brand & -80 & -0.1985 \\
Awards & -120 & -0.32 \\
Alcohol level & -138 & -0.3595 \\
Attractive front label & -155 & -0.3945 \\
\hline
\end{tabular}

Source: Database analyse (2019).

as the most important (Countbest) less the number of times that attribute was pointed as less important (Countworst). The Countbest and Countworst found for each of the nine attributes of this study are shown in Table 1.

From then on the standard score was calculated, which is the level of importance divided by the number of times each attribute appears in the combination multiplied by the number of questionnaires answered, as can be observed in the following equation:

$$
\text { Standard score }=\frac{\text { COUNTbest }- \text { COUNTworst }}{4 n}
$$

After applying the equation, the results are shown in tables in the following section.

\section{Results}

The sample studied was dominated by consumers between the ages of 20 and 45 years, and the number of respondents of the male and female gender was balanced (57\% female and $43 \%$ male). The majority of respondents (54\%) belong 
Table 3. Exploratory price attribute hiphotesis.

\begin{tabular}{|c|c|c|c|c|c|c|}
\hline Exploratory hyphotesis & 1 & 2 & 3 & 4 & 5 & $N^{\circ}$ of response \\
\hline Wines are expensive & $11 \%$ & $24 \%$ & $35 \%$ & $25 \%$ & $5 \%$ & 100 \\
\hline $\begin{array}{l}\text { Low price is important when buying } \\
\text { a wine. }\end{array}$ & $15 \%$ & $27 \%$ & $24 \%$ & $26 \%$ & $8 \%$ & 100 \\
\hline $\begin{array}{l}\text { I do not like wines with high alcohol } \\
\text { content. }\end{array}$ & $16 \%$ & $21 \%$ & $27 \%$ & $24 \%$ & $12 \%$ & 100 \\
\hline $\begin{array}{l}\text { I already bought wine just because it had } \\
\text { an attractive front label. }\end{array}$ & $32 \%$ & $31 \%$ & $7 \%$ & $25 \%$ & $5 \%$ & 100 \\
\hline $\begin{array}{l}\text { I prefer to take wines that have already } \\
\text { been awarded. }\end{array}$ & $15 \%$ & $22 \%$ & $34 \%$ & $20 \%$ & $9 \%$ & 100 \\
\hline I know many brands of wine. & $5 \%$ & $25 \%$ & $26 \%$ & $33 \%$ & $13 \%$ & 100 \\
\hline
\end{tabular}

to class $\mathrm{C}$, that is, they have income between 4 and 10 minimum wages (SM) according to the classification of social class adopted by the Brazilian Institute of Geography and Statistics (IBGE). While class D (with family income of 2 to $4 \mathrm{SM}$ ) is represented by $18 \%$ of the participants of the research. Regarding the frequency of wine consumption in Porto Alegre, most consumers drink wine only once a month or very rarely.

\section{Relevance of wine atributes to Porto Alegre consumers}

Through the Best-Worst scale the degree of relevance of attributes was identified in relation to their influence on the decision to buy a product. The classification of that divides attributes into: a) important ones - those that are considered important at the time of product choice but do not determine the purchase of the product - and b) determinants - those attributes that influence the decision of the consumer.

After analyzing the data collected through the BW scale, 5 (five) of the 9 (nine) investigated attributes had a negative relevance level and therefore were classified only as important. They are: Price, brand, award, alcoholic level and attractive front label as shown in Table 2.

Four of the nine attributes of the wine were positively evaluated by the consumers survey, and thus were considered the determinants for the purchase: grape variety, wine origin, harmonization with food and counterlabel information. When analyzing the answers of the items that measure the importance of the price attribute on the purchase decision of the consumer, it is perceived that this really is not a very significant attribute for the researched sample as can be observed in Table 3.

Only $30 \%$ of respondents find wines expensive, while $35 \%$ of respondents disagree with or disagree with this view. The low influence of the price attribute for the consumers of this sample is even more explicit when the results indicate that $34 \%$ of the respondents disagree or totally disagree that the low price is an important aspect in the purchase of this drink.

The wine brand and the award were also attributes negatively indicated by the BW scale not having a significant weight for wine consumers at the time of purchase. This result may be indicative of absence or deficiency in the marketing plan of wine producers. The low dissemination and promotion of the brands and the prizes received by the wines can make it difficult
Table 4. Attributes of wine classified as determinants by BW Score.

\begin{tabular}{|lcc|}
\hline Atributtes & Level of relevance & Score \\
\hline Grape variety & 156 & 0.3835 \\
Wine of origin & 141 & 0.357 \\
Harmonization with food & 120 & 0.2895 \\
$\begin{array}{l}\text { Over the counter-label } \\
\text { information }\end{array}$ & 92 & 0.2405 \\
\hline
\end{tabular}

Source: Database analyse (2019).

to establish the product in the market, as well as the construction of a relationship of trust with the consumer to the point of influencing him in his decision to buy. By analyzing the results of the Li kert scale, one can better understand the consumer's perception of these two attributes. Only $46 \%$ of consumers agree fully or only agree that they know many wine brands. And although consumers know a large number of brands, this aspect was not able to make the brand attribute had its level of relevance positively classified by the respondents. The low relevance of the award is evident in the sentence "I prefer to take wines that have already been awarded", because the results indicate that only $29 \%$ of consumers agree or fully agree with this statement.

The alcoholic strength of the wine was also classified as an important attribute. Regarding consumer considerations in terms of the alcoholic strength of the drink, the results found on the Likert scale show that $27 \%$ of consumers are indifferent about this attribute, whereas $40 \%$ do not like wines with high alcohol content.

Finally, the attractive front label appears as the last important attribute. The low relevance of the frontal label can also be observed in the results found by the Likert scale, since $63 \%$ of consumers disagree or totally disagree with the statement "I already bought wine just because it had an attractive frontal label."

Four of the nine attributes of the wine were positively evaluated by the consumers surveyed, and thus were considered as determinants for the purchase of the beverage: grape variety, wine origin, food harmonization and counter-label information, as presented in Table 4.

When weighing the determining attributes for the consumers of Porto Alegre, the grape variety was the attribute that most influenced the choice of wine. It is interesting to note that consumers prefer white grapes as indicated in 5. 
Table 5. Exploratory hypotheses of determining attributes.

\begin{tabular}{|c|c|c|c|c|c|c|}
\hline Exploratory hyphotesis & 1 & 2 & 3 & 4 & 5 & $N^{\circ}$ of responses \\
\hline Wines made from red grapes are tastier. & $7 \%$ & $21 \%$ & $26 \%$ & $25 \%$ & $21 \%$ & 100 \\
\hline I like to drink wine with food. & $5 \%$ & $6 \%$ & $13 \%$ & $43 \%$ & $35 \%$ & 100 \\
\hline $\begin{array}{l}\text { I find the wine tastier when harmonizing } \\
\text { with } \\
\text { the food. }\end{array}$ & $3 \%$ & $8 \%$ & $22 \%$ & $32 \%$ & $35 \%$ & 100 \\
\hline $\begin{array}{l}\text { I read the information on the back label } \\
\text { to buy a wine. }\end{array}$ & $6 \%$ & $11 \%$ & $18 \%$ & $36 \%$ & $27 \%$ & 100 \\
\hline $\begin{array}{l}\text { The information on the label helps me to } \\
\text { know the best wine. }\end{array}$ & $5 \%$ & $3 \%$ & $15 \%$ & $49 \%$ & $28 \%$ & 100 \\
\hline $\begin{array}{l}\text { International wines are more delicious } \\
\text { than Brazilian wines. }\end{array}$ & $15 \%$ & $18 \%$ & $34 \%$ & $20 \%$ & $13 \%$ & 100 \\
\hline $\begin{array}{l}\text { Brazilian wines are as good as imported } \\
\text { wines. }\end{array}$ & $4 \%$ & $23 \%$ & $33 \%$ & $19 \%$ & $21 \%$ & 100 \\
\hline $\begin{array}{l}\text { Red wines are easier to harmonize than } \\
\text { whites }\end{array}$ & $8 \%$ & $27 \%$ & $30 \%$ & $24 \%$ & $11 \%$ & 100 \\
\hline
\end{tabular}

Source: Database analyse (2019).

The origin of wine is the second determining characteristic for the consumer at the time of purchase. However, the consumer does not have a clear and formed opinion about the quality of national versus international wines as can be observed in the results obtained by the Likert scale. In the sentence "International wines are tastier than Brazilian wines," $33 \%$ of consumers surveyed agree or fully agree, while $33 \%$ disagree or totally disagree. On the other hand, $40 \%$ of respondents agree or fully agree that Brazilian wines are as good as imported wines.

The third determining attribute was the harmonization with food, confirmed by the results of the exploratory hypotheses of the Likert scale, since $78 \%$ of respondents like to drink wine with food and $67 \%$ find wine tastes better when harmonized with food. Although these results indicate that the consumer values harmonization, no evidence has been found that he has sufficient knowledge to make such a combination correctly. This suspicion is intensified by observing the Likert scale, as consumers have doubts about some important aspects of harmonization. Only $35 \%$ of consumers are aware that red wines are more difficult to harmonize by disagreeing with or disagreeing completely with the phrase "Red wines are easier to harmonize than whites."

The back label information was the fourth determining attribute for the consumer at the time of purchase. According to the results found on the Likert scale, $63 \%$ of respondents read the information on the back label before buying the wine and $74 \%$ consider that this information helps them to know the best wine. This finding corroborates the arguments of Lockshin \& Hall (2003) that consumers use the information on the back label to choose a wine. In addition, the relevance of the counter-label to wine consumers confirms the claims of Mello (2002) and Sloan (2005) on the need to search for consumer knowledge to better appreciate the beverage.

\section{Final considerations}

As a trend, it can be emphasized that the variety of grape, origin of wine, harmonization with food and information contained in the over counter label, were, respectively, the determining attributes for the wine consumer of Porto Alegre in their purchase decision.
Two attributes are highlighted as determinants both in the countries surveyed by Goodman et al. (2007), Magistris et al. (2010), Szabo and Szeles (2006), Johnson and Bastian (2007), Lewis (2010) and McGarry and Thompson (2010). They are: grape variety and wine of origin. These two attributes have an interconnection, because by planting the same grape variety in different places and wines of different flavors are obtained. But it is necessary to investigate more deeply the country and grape variety most consumed in Porto Alegre, since a clear opinion about the quality of national and international wines was not observed, although the wine of origin was the second most relevant attribute.

In this research as well as in the research of Goodman et al. (2007) the price was indicated negatively having little relevance to the wine consumer. In contrast to some studies where price was a fundamental attribute in the wine purchase (Mcgarry, 2010; Thompson, 2010) or was positively indicated (Magistris et al., 2011).

Attributes like the appearance of the label and award had little influence on the consumer's decision. This result may indicate that such attributes are currently receiving little effort from the marketing team. The continuity of this research can help the wine industry in producing wines that meet the profile of its consumers, minimizing the risk of losing existing customers, and identifying which brands of wines are its competitors.

\section{References}

[1] R.D. Blackwell, P.W. Miniard, J.F. Engel, Cengage Learning São Paulo (2009)

[2] R.F.F. Cardeira, "Factores Críticos de Sucesso no Mercado do Vinho em Portugal e a Sustentabilidade do Sector Vitivinícola”. Dissertação de Mestrado em Engenharia e Gestão e Industrial (Universidade Técnica de Lisboa, Lisboa, 2009)

[3] K. Chrzan, M. Patterson, "Testing for the Optimal Number of Attributes in MaxDiff Questions". Sawtooth Software. Available in: http://www. sawtoothsoftware.com/download/techpap/ mdoptimalatts.pdf. Acessed on march 23, 2019 (2006) 
[4] G.A. Churchill, P. Peter, Marketing criando valor para os clientes Saraiva São Paulo (2005)

[5] J.F. Engel, R.D. Blackwell, P.W. Miniard, "Comportamento do Consumidor". Livros Técnicos e Científicos Editora S.A. Rio de Janeiro (2000)

[6] S. Erdem, D. Rigby, A. Wossink, "Who is most responsible for ensuring the meat we eat is safe?" Ageconsearch, Edinburgh, http:// ageconsearch. umn. edu/handle/91813. Acessed on march 20, 2019 (2010)

[7] F.S. da Espinoza, A.S. Hirano, RAC, 7, 97 (2003)

[8] A.F. Fernandes Neto, "A Importância da Globalização para as Empresas Brasileiras" Thesis, São Paulo, 5(3): 1-20, Available in: http://www. cantareira.br/thesis2/n5a3/alvaro.pdf. Acessed on march 2, 2019 (2006)

[9] S.L. Forbes, "The influence of individual characteristics, product attributes and usage situations on consumer behaviour: An exploratory study of the New Zealand, Australian, UK and US wine markets" Dissertação de Doutorado em Filosofia em Marketing Lincoln University (2008)

[10] S. Galvão, "A cozinha e seus vinhos: Receitas rápidas com muita classe". Editora Senac, São Paulo (2004)

[11] A.C. Gil, "Como elaborar projetos de pesquisa" Atlas, São Paulo (2002)

[12] J. Giraldi, de M.E., A.A. Ikeda, A Influência dos Valores Pessoais dos Consumidores no "Efeito país de Origem” (Anais do XXXI ENANPAD, 2007), p. 1

[13] S. Goodman, L. Lockshin, E. Cohen, "BestWorst scaling: A simple method to determine drinks and wine style preferences" (2005)

[14] Wine Preferences. Available in: http://www. winepreferences.com/resources/page28/ files/page28_1.pdf, acessed on march 20, 2019

[15] S. Goodman, L. Lockshin, E. Cohen, Wine Ind. J. 22, 42 (2007)

[16] E. Groot, "Choice experiments with best-worst alternatives to understand consumer behaviour: application to peaches with Protected Designation of Origin (PDO) Calanda", Dissertação de Doutorado em Economia, Facultad de Economía y Empresa, Universidad de Zaragoza, Zaragoza (2011)

[17] L. Guilhoto, F.M. de, “A influência do país de origem na percepção do consumidor sobre a qualidade dos produtos" Caderno de Pesquisas em Administração, 8 (2001)

[18] D.I. Hawkins, D.L. Mothersbaugh, J.B. Roger, "Comportamento do consumidor: construindo a estratégia de marketing" Elsevier, Rio de Janeiro (2007)

[19] T. Johnson, S. Bastian, Australian J. Grape and Wine Res. 13, 186 (2007)

[20] P. Kotler, "Administração de Marketing: análise, planejamento, implementação e controle"Atlas, São Paulo (1998)

[21] A.L. Las Casas, "Administração de marketing: conceitos, planejamento e aplicações à realidade brasileira" Atlas, São Paulo (2008)

[22] K.A. Lattey, B.R. Bramley, I.L. Francis, M.J. Herderich, S. Pretorius, Wine Ind. J. 22 31 (2007)
[23] R.L. Lewis, "Exploring consumer preferences in the United States wine market: Market segmentation applying best-worst scaling. Generation e Emphasis" Dissertação de Mestrado em Marketing, Department of Marketing and Statistics, Aarhus School of Business, Aarhus (2010)

[24] L. Lockshin, E. Cohen, S. Goodman, Wine Ind. J. 24, 42 (2009)

[25] L. Lockshin, J. Hall, "Consumer Purchasing Behaviour for Wine: What We Know and Where We are Going", Academy of Wine Business, Colloquium in Wine Marketing 2003, http:// academyof winebusiness. com/wp-content/ uploads/2010/05/File-030.pdf, Acessed on april 10, 2019 (2003)

[26] M.J.S. Louro, "Modelos de Avaliação de Marca". Rae - Revista de Administração de Empresas 40, 26 (2000)

[27] R. Lunardo, R. Guerinet, "The influence of label on wine consumption: its effects on young consumers' perception of authenticity and purchasing behavior". Anais do CONGRESS EAAE Seminar (França, University of Reims, 2007), p. 68

[28] T.de. Magistris, E. Groot, A. Gracia, L.M. Albisu, "Consumers preferences for wine in Spain: bestworst scaling methodology", Anais do CONGRESS EAA. Espanha, Unidad de Economía Agroalimentaria y de los Recursos Naturales (2011)

[29] J. Marti, "A best-worst scaling survey of adolescents' level of concern for health and no health consequences of smoking", ECN, Seminários Matuszewski, Available in: http://www.ecn. ulaval.ca/seminaire/article//a_best_worst scaling_survey_of_adolescents_level_of _ concern_for_health_and_non_health_ consequences/, acessed on march 10, 2019 (2012)

[30] M.W. Mcgarry, M. Thompson, The Importance of the information on the back label of a wine bottle on the purchase decision Anais da AARES pre-conference workshops (Australia, Adelaide, 2010)

[31] L.M.R. de Mello, "Tendência de Consumo e Perspectivas do Mercado de Vinhos no Brasil", Embrapa Uva e Vinho. Rio Grande do Sul, http:// www. cnpuv . embrapa.br/publica/artigos/ tendencia.pdf, acessed on march 5, 2019 (2002)

[32] F. Miranda, "Arte e vinho", Axel Books do Brasil Editora (Rio de Janeiro, 2001)

[33] S. Mueller, et al., "How does shelf information influence consumers' wine choice?" The Australian Wine Research Institute, available in: http:// winepreferences.com/resources/page59/ files/page59_1.pdf. Acessed on april 5, 2019 (2009)

[34] B. Orme, "Accuracy of HB Estimation in MaxDiff Experiments" Sawtooth Software, Available in: http: //www.sawtoothsof tware.com/download/ techpap/maxdacc.pdf, Acessed on march 20, 2019 (2005)

[35] D. Pinto, "Manual didático do vinho: iniciação a enologia" Editora Anhembi Morumbi, São Paulo (2009) 
[36] M. Roese, Revista de Sociologia e Política 16, 71 (2008)

[37] T. Ruão, M. Farhangmer, "A imagem de marca: análise das funções de representação e apelo no marketing das marcas, Um estudo de caso" Available in: http://repositorium.sdum.uminho.pt/ bitstream/1822/1985/3/truao_Farhangmer_ CMark_2000.pdf, acessed on march 20, 2019 (2000)

[38] Sawtooth Software, "The MaxDiff/Web System Technical Paper" Available in: http://www. sawtoothsoftware.com/download/techpap/ maxdifftech.pdf, acessed on may 20, 2019 (2007)

[39] J.N. Shef, B. Mittal, B.I. Newman, "Comportamento do Cliente: Indo além do comportamento do consumidor" Atlas, São Paulo (2001)

[40] L.G. Shiffman, L.L. Kanuk, "Comportamento do consumidor" LTC, Rio de Janeiro (2009)

[41] D. Sloan, (Org.) "Gastronomia, restaurantes e comportamento do consumidor" Manole, São Paulo (2005)
[42] N. Stefano, A. Capoval, L.P. Godoy, "Explorando conceitos e modelos sobre o processo de decisão de compra do consumidor em função da mudança de hábito alimentar". Anais do IX Congresso Nacional de Excelência em Gestão (Rio de Janeiro, 2008), p. 1

[43] Z. Szabo, Z. Szeles, "Analysing Wine Buying Behaviour in Hungarian Hypermarkets" Anais da International Association Of Agricultural Economists Conference (Gold Coast, Australia, 2006), Available in: http://ageconsearch.umn. edu/handle/25235, acessed on march 20, 2019

[44] F. Tibola, V. Vieira, J. Sanzovo, "Atributos importantes na compra de notebooks: um estudo exploratório", Anais do VII SEMEAD (São Paulo, 2004)

[45] F.T. Urdan, L. Nagão, "Atributos intrínsecos e extrínsecos nas avaliações dos consumidores e efeitos na qualidade, valor e satisfação", Anais do XII SEMEAD São Paulo (2004) 